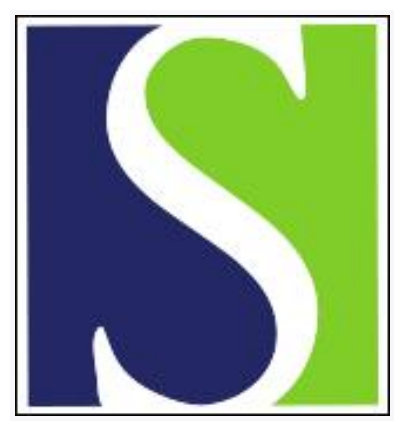

Scand J Work Environ Health 1989;15(1):64-68

https://doi.org/10.5271/sjweh.1890

Issue date: Feb 1989

Inhibition of synaptosome membrane-bound integral enzymes by organic solvents.

by Korpela M

Affiliation: Department of Biomedical Sciences, University of Tampere, Finland.

This article in PubMed: www.ncbi.nlm.nih.gov/pubmed/2522239

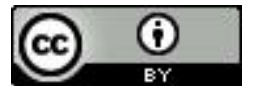




\title{
Inhibition of synaptosome membrane-bound integral enzymes by organic solvents
}

\author{
by Marja Korpela, MD ${ }^{1}$

\begin{abstract}
KORPELA M. Inhibition of synaptosome membrane-bound integral enzymes by organic solvents. Scand $J$ Work Environ Health 1989;15:64-68. The possible mechanism of the depressive effect of organic solvents on the central nervous system (CNS) was studied with synaptosome membranes as a model. The changes in the activities of the membrane-bound integral enzymes acetylcholinesterase, total adenosinetriphosphatase, and magnesium-activated adenosinetriphosphatase were determined after treatment with different concentrations of organic solvents in vitro. Aromatic hydrocarbons and chlorinated aliphatic hydrocarbons inhibited all the enzyme activities concentration dependently. Alcohols had no significant effect at the same dose levels. The results of the present study suggest that the CNS depressive effect of organic solvents may be based on their interaction with membrane integral proteins.
\end{abstract}

Key terms: alcohols, aliphatic chlorinated hydrocarbons, aromatic hydrocarbons, membrane effects.

Organic solvents are widely used in industry (eg, in spray painting, glueing, degreasing) and in households. Their most important toxic effect is the depression of the activity of the central nervous system (CNS) by a mechanism which is still unclear. The action of a wide variety of compounds capable of inducing anesthesia is thought to be either on lipid or on protein components of the membrane. One of the theories on anesthesia suggests that the potency of anesthetics is directly proportional to the lipid solubility of the anesthetic in question and that changes in membrane lipids are the critical factors leading to anesthesia (1). However, the action of several anesthetics does not fit this theory. Another theory, which is supported by the studies of Franks \& Lieb (2-4), suggests that lipid-soluble anesthetics can interact nonspecifically with large hydrophobic regions of membrane proteins.

In previous studies by my co-workers and I, the interaction of organic solvents with integral proteins of erythrocyte membranes has been demonstrated in humans and rats at anesthetic and lower concentrations $(5-7)$. In the present study I have investigated the changes in the activities of acetylcholinesterase (AChE), total adenosinetriphosphatase (total ATPase), and magnesium-activated adenosinetriphosphatase $\left(\mathrm{Mg}^{2+}-\mathrm{ATP}\right.$ ase $)$ in rat synaptosome membranes exposed to organic solvents under in vitro conditions to evaluate further the mechanism of the solvent-induced CNS depression on the cell membrane.

\footnotetext{
1 Department of Biomedical Sciences, University of Tampere, Tampere, Finland.
}

Reprint requests to: Dr M Korpela, Department of Biomedical Sciences, University of Tampere, PO Box 607, SF-33101 Tampere, Finland.

\section{Materials and methods}

\section{Organic solvents}

The organic solvents studied were benzene, toluene, styrene, and $o$-xylene (analytical grade, E Merck, Darmstadt, Federal Republic of Germany), 1,1,1-trichloroethane (analytical grade, Fluka AG, Buchs, Switzerland), trichloroethylene, 1,1,2,2-tetrachloroethane, and tetrachloroethylene (analytical grade, E Merck), methanol (analytical grade, E Merck), ethanol (minimum $99.5 \%$ grade of purity, Oy Alko Ab, Finland), 1-propanol, and 1-butanol (analytical grade, $\mathrm{E}$ Merck).

\section{Preparation of synaptosomes}

Male Spraque-Dawley rats (weight $200 \mathrm{~g}$ ) were decapitated. The cerebrum was gently separated from the cerebellum, brain stem, and meninges and immediately placed in ice.

The isolation of the synaptosomes was performed by the Percoll gradient method (8). Briefly, the samples were homogenized at 800 revolutions/min with a Teflon-glass homogenizer in isolation medium containing $0.32 \mathrm{M}$ sucrose, $5 \mathrm{mM} \mathrm{N}$-2-hydroxyethyl-piperazine-N'-2-ethane-ethylenediaminetetraacetic acid (HEPES), pH 7.5 (Sigma Chemical Co, St Louis, Missouri, United States) and $0.1 \mathrm{mM}$ ethylenediaminetetraacetate (EDTA) (Sigma Chemical Co), and centrifuged at $1000 \mathrm{~g}$ for $10 \mathrm{~min}$ to give a pellet containing nuclear and cell debris and a low-speed supernatant, which was further centrifuged at $12000 \mathrm{~g}$ for $20 \mathrm{~min}$ to produce the crude mitochondral pellet, which was resuspended in $3 \mathrm{ml}$ of isolation medium per gram of original wet tissue and homogenized gently.

The stock solution of isosmotic Percoll (SIP) (Sigma Chemical $\mathrm{Co}$ ) was made by the addition of nine parts (volume/volume) of the original Percoll solution 
to one part (volume/volume) of $2.5 \mathrm{M}$ sucrose, and the lower density media by the dilution of SIP with a solution containing $0.25 \mathrm{M}$ sucrose, $5 \mathrm{mM}$ HEPES ( $\mathrm{pH}$ 7.2), and 0.1 mM EDTA. The $\mathrm{pH}$ of the gradient solutions was adjusted to 7.5. Percoll step gradients were made by the overlayering of $4 \mathrm{ml}$ of $16 \%$ Percoll solution with $4 \mathrm{ml}$ of $10 \%$ Percoll solution. The resuspended mitochondrial pellet was diluted with eight volumes of $8.5 \%$ Percoll solution to give a final concentration of Percoll $7.5 \%$, and $4.5 \mathrm{ml}$ of this suspension was layered onto the $10 / 16 \%$ Percoll gradients. After centrifugation at $15000 \mathrm{~g}$ for $20 \mathrm{~min}$, the synaptosomes were collected and stored in ice until used. All the procedures used for preparing the synaptosomes were carried out at $0-4^{\circ} \mathrm{C}$.

\section{Determination of acetylcholinesterase activity}

In determining the AChE activity in synaptosome membranes, the method of Ellman et al (9) was used.

In the reaction mixture [ $10.4 \mathrm{ml}$ of synaptosome suspension and $2.6 \mathrm{ml}$ of $0.1 \mathrm{M}$ phosphate buffer $(\mathrm{pH}$ 8.0)], different concentrations of organic solvents were added with a Hamilton microsyringe. After $30 \mathrm{~min}$ of incubation, in 3-ml, glass-stoppered tubes at $37^{\circ} \mathrm{C}$ with continuous shaking, the samples were transferred into a thermostated cuvette, and $100 \mu \mathrm{l}$ of 5,5-dithiobis(2-nitrobenzoic acid) (DTNB) (Sigma Chemical Co) was added. The absorbance at $412 \mathrm{~nm}$ was set at zero, and the reaction was started by the addition of $20 \mu \mathrm{l}$ of $0.075 \mathrm{M}$ acetylthiocholine iodide. The change in the absorbance was measured for $5 \mathrm{~min}$. The AChE activity was expressed as moles of substrate hydrolyzed per minute per gram of protein, and the activities of the solvent-treated samples were given as the percentage of the activities of the controls.

\section{Determination of adenosinetriphosphatase activities}

In the determination of the ATPase activities, a modification of the discontinuous method based on the determination of inorganic phosphate (10) was used.

The organic solvents were added to the 2 -ml reaction mixture [ $50 \mathrm{mM}$ tris(hydroxymethyl)aminomethanehydrochloride acid (Tris-HCl) buffer $(\mathrm{pH}$ 7.6), $1.5 \mathrm{mM}$ adenosine-5'-triphosphate (ATP) (Sigma Chemical Co), $6.0 \mathrm{mM}$ magnesium chloride, $100 \mathrm{mM}$ sodium chloride, $20 \mathrm{mM}$ potassium chloride, and 0.1 $\mathrm{ml}$ of synaptosome suspension] with a Hamilton microsyringe, and the tubes were glass-stoppered and mixed. The total ATPase activity was measured with sodium $\left(\mathrm{Na}^{+}\right)$, potassium $\left(\mathrm{K}^{+}\right)$, and magnesium $\left(\mathrm{Mg}^{2+}\right)$ ions present in the reaction mixture, and $\mathrm{Mg}^{2+}$-ATPase activity with only the magnesium ion present in the mixture. After $1 \mathrm{~h}$ of incubation at $37^{\circ} \mathrm{C}$ with continuous shaking, $2 \mathrm{ml}$ of ice-cold $10 \%$ trichloroacetic acid (TCA) was added. After centrifugation at $3000 \mathrm{~g}$ for $5 \mathrm{~min}, 1 \mathrm{ml}$ of the supernatant was removed for the assay, and $3 \mathrm{ml}$ of $0.1 \mathrm{~N}$ sodium acetate, $0.4 \mathrm{ml}$ of $1 \%$ molybdate/ $1 \mathrm{~N}$ sulfuric acid solu- tion, and $2 \mathrm{ml}$ of ascorbic acid were added. The absorbances of the samples were read at $770 \mathrm{~nm}$ after $25 \mathrm{~min}$. The enzyme activities were expressed as moles of inorganic phosphate formed per hour per milligram of protein, and the activities of the solvent-treated samples were given as the percentage of the activities of the controls.

\section{Protein determination}

The method described by Lowry et al (11) was used for the protein determinations.

\section{Statistical methods}

All the solvent concentrations were measured in triplicate, and three independent measurement series were carried out for each solvent studied. In the statistical calculations, Student's t-test (4 degrees of freedom) was used.

\section{Results}

\section{Acetylcholinesterase activity}

The AChE activity of the control samples was 0.10 (SE 0.05 ) mmol of substrate hydrolyzed per minute per gram of protein.

The aromatic hydrocarbons and chlorinated aliphatic hydrocarbons inhibited the AChE activity concentration dependently. AChE was significantly $(\mathrm{P}<0.001)$ inhibited by toluene, styrene, and $o$-xylene at concentrations of $3 \mathrm{mM}$ or higher and by benzene at concentrations of $9 \mathrm{mM}(\mathrm{P}<0.01)$ or higher (figure 1). Of the chlorinated aliphatic hydrocarbons, 1,1,2,2-tetrachloroethane was strongly AChE-inhibiting, and it showed a clear concentration dependency. The other solvents of this group had a slighter but still significant inhibitory effect, ie, trichloroethylene and tetrachloroethylene from the concentration of $3 \mathrm{mM}$ up $(\mathrm{P}<0.01)$ and $1,1,1$-trichloroethane from the concentration of $6 \mathrm{mM}(\mathrm{P}<0.05)$ up (figure 1$)$. Of the alcohols studied, 1-butanol was slightly AChE-activating at the highest concentrations (20 and $30 \mathrm{mM}$ ). Methanol, ethanol, and 1-propanol had no effect on the enzyme activities (figure 1).

\section{Adenosinetriphosphatase activities}

The control samples had a total ATPase activity of 0.54 (SE 0.01) $\mu \mathrm{mol}$ of inorganic phosphate per hour per milligram of protein and a $\mathrm{Mg}^{2+}$-ATPase activity of 0.21 (SE 0.01) $\mu \mathrm{mol}$ of inorganic phosphate per hour per milligram of protein.

The total ATPase was significantly inhibited by all the aromatic hydrocarbons at concentrations of $3 \mathrm{mM}$ or higher. [The significance at $3 \mathrm{mM}$ was $\mathbf{P}<0.05$ for benzene and styrene, $\mathrm{P}<0.01$ for 0 -xylene, and $\mathrm{P}<0.001$ for toluene (figure 2).] At the two highest concentrations, styrene and $o$-xylene were the most effective compounds of this group. 1,1,2,2-Tetrachloro- 

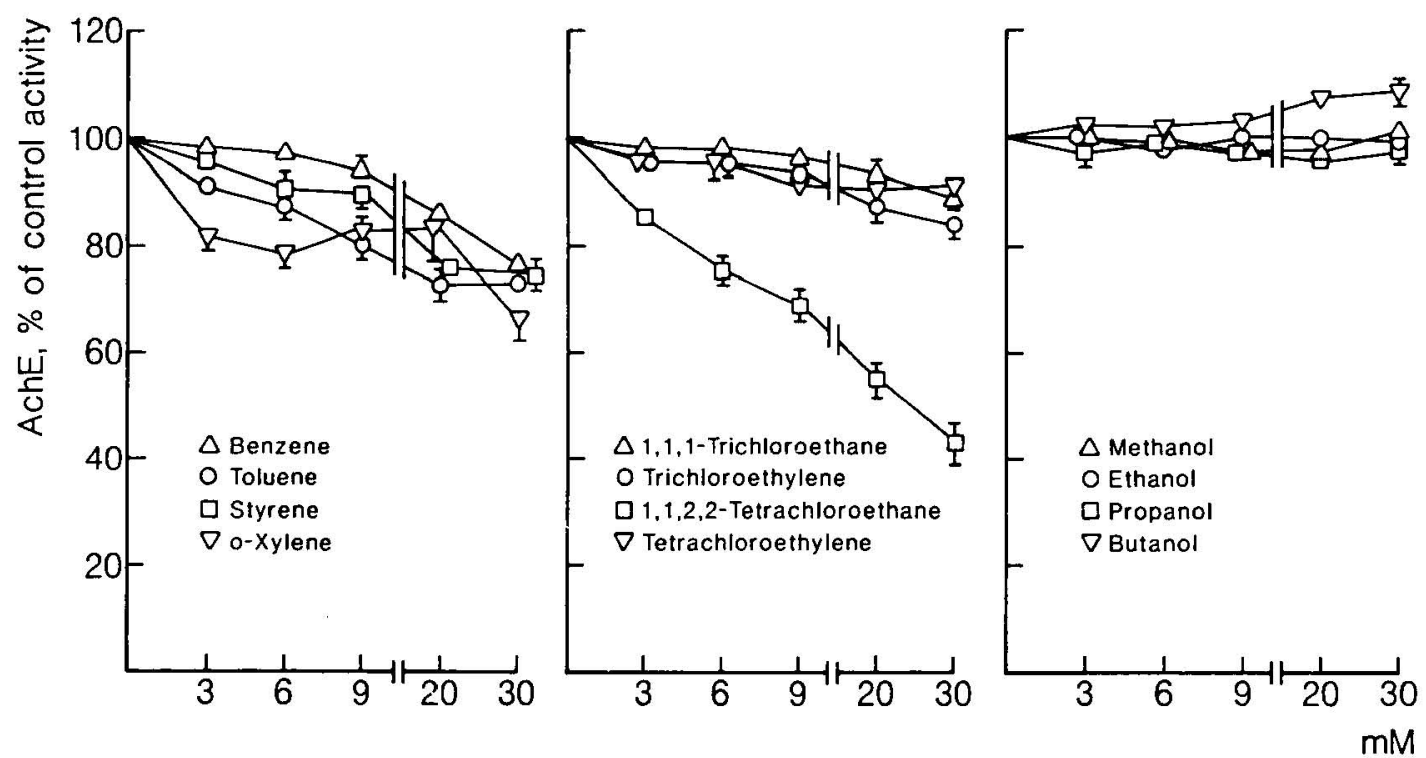

Figure 1. Effect of different concentrations of aromatic hydrocarbons, chlorinated aliphatic hydrocarbons, and alcohols on acetyicholinesterase (AChE) activity in rat synaptosome membrane. The means and standard error of the means of nine independent measurements are shown.
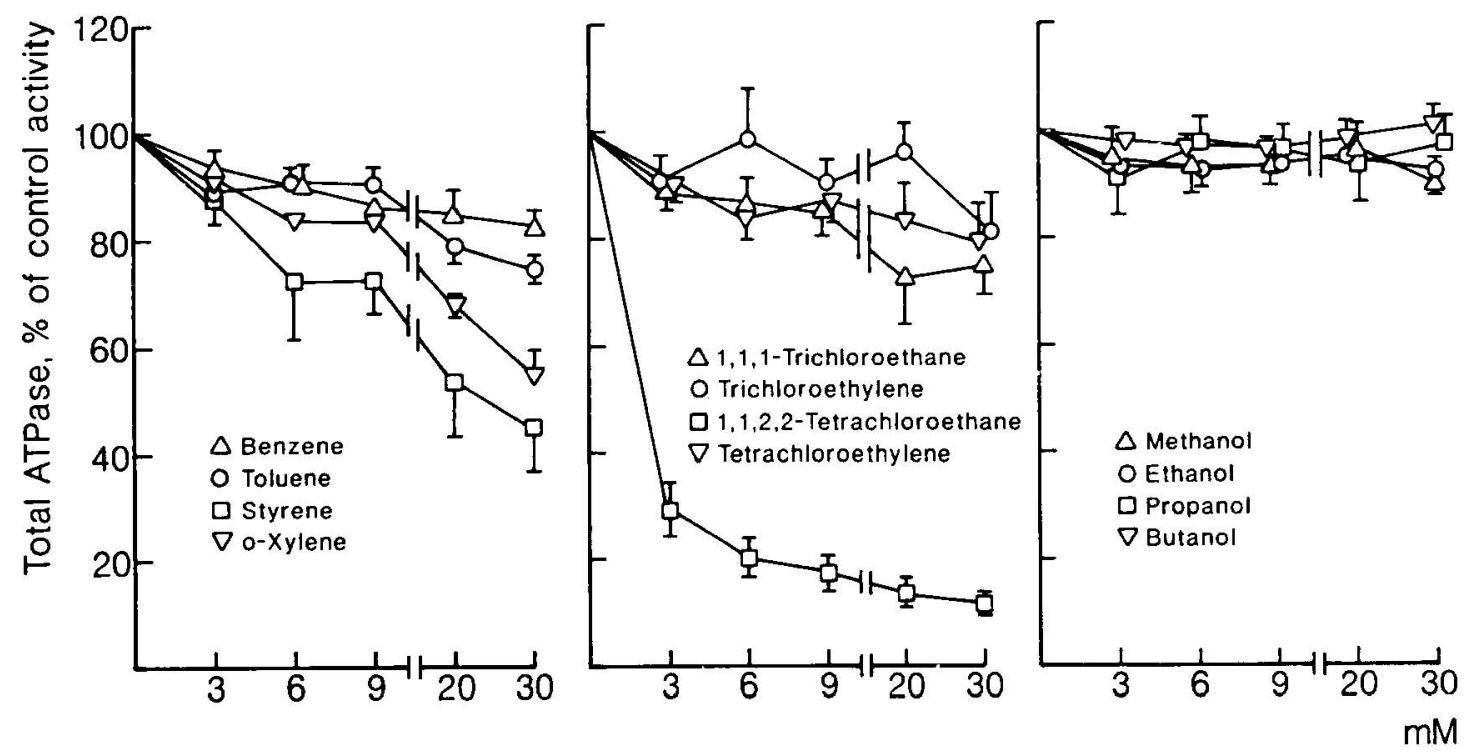

Figure 2. Effect of different concentrations of aromatic hydrocarbons, chlorinated aliphatic hydrocarbons, and alcohols on total adenosinetriphosphatase (ATPase) activity in rat synaptosome membrane. The means and standard error of the means of nine independent measurements are shown.

ethane inhibited total ATPase even more than AChE at all the concentrations. The other chlorinated aliphatic hydrocarbons were inhibitory, too, but to a less extent (figure 2). Alcohols had no effect on enzyme activity.

$\mathrm{Mg}^{2+}$-ATPase was inhibited by all the aromatic hydrocarbons and, of the chlorinated aliphatic hydrocarbons, by 1,1,2,2-tetrachloroethane, tetrachloroethylene, and trichloroethylene. Alcohols had no significant effect on the $\mathrm{Mg}^{2+}-$ ATPase activity (figure 3 ).

\section{Discussion}

The results of the present study show that the studied aromatic hydrocarbons and chlorinated aliphatic hydrocarbons inhibit AchE and ATPase activities in rat synaptosome membrane concentration dependently. These results agree with previous findings with erythrocyte membrane (5-7). Organic solvents affect both erythrocyte membrane AChE, which is situated on the outer half of the membrane, and ATPase, the location of which is mainly on the cytoplasmic side of 

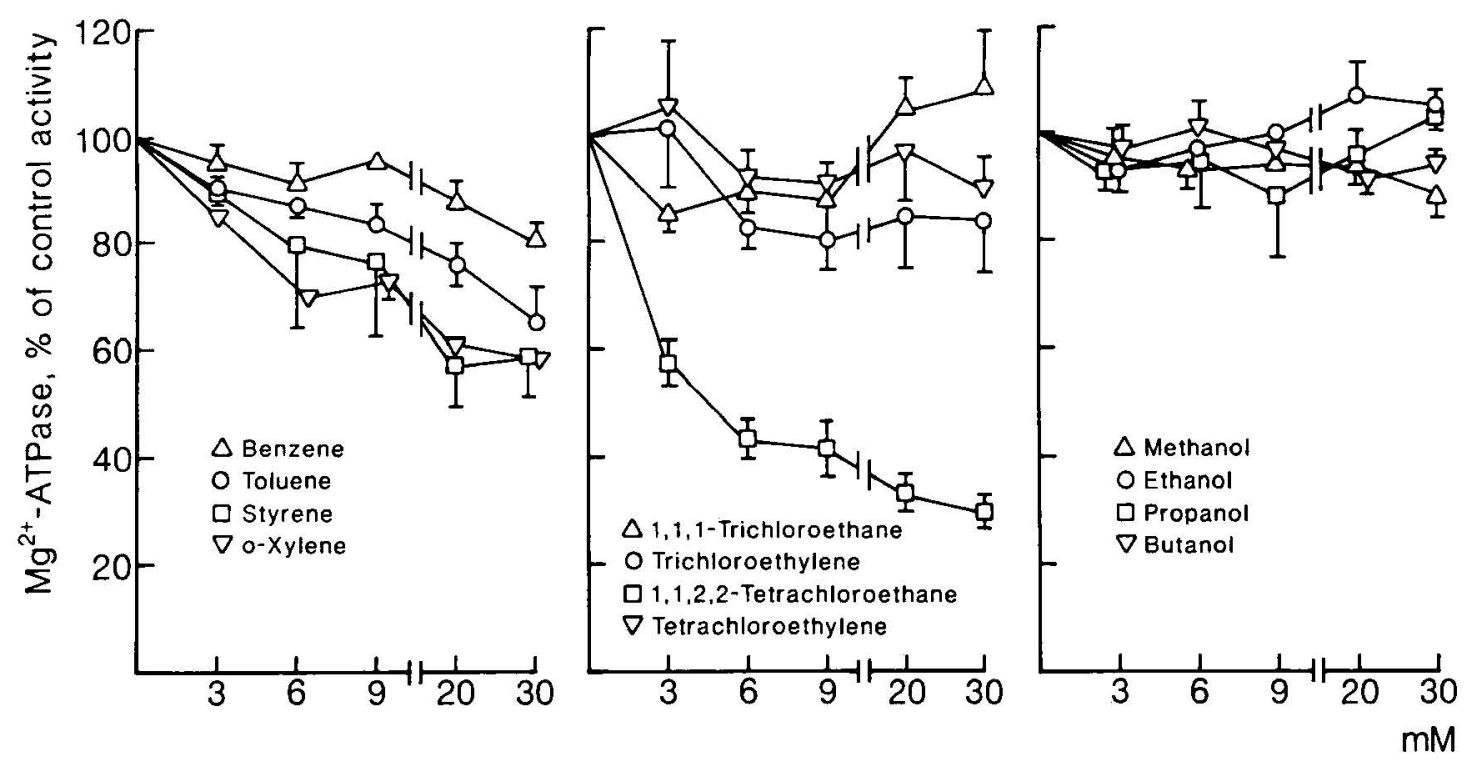

Figure 3. Effect of different concentrations of aromatic hydrocarbons, chlorinated aliphatic hydrocarbons, and alcohols on magnesium-activated adenosinetriphosphatase ( $\mathrm{Mg}^{2+}$-ATPase) activity in rat synaptosome membrane. The means and standard error of the means of nine independent measurements are shown.

the erythrocyte membrane (12). Many other compounds have also been shown to inhibit both erythrocyte and synaptosome membrane enzymes, eg, local anesthetics $(13-16)$, fatty acids $(17,18)$, and alcohols (19-23). The similarity of the effects of organic solvents on synaptosome membrane and erythrocyte membrane suggests that even the erythrocyte membrane is a suitable model in studies of the mechanism of the anesthetic-like CNS effects of organic solvents.

The enzyme inhibition induced by organic solvents in the present study was mainly related to the lipid solubilities of the solvents. However, 1,1,2,2-tetrachloroethane, which is the most toxic of the chlorinated hydrocarbons, was a very potent enzyme inhibitor, although its lipid solubility is low in comparison to, eg, that of the aromatic hydrocarbons.

The molecular structure of a compound may be one of the factors determining its action on biological membranes. Usually, the CNS-depressive properties of solvents are enhanced by halogenation and by an increase in the length of the carbon chain. It has also been shown that the inhibition of AChE by local anesthetics is dependent on the structure of these anesthetics (24).

In the present study, the ATPase activities were inhibited more than the AChE activity, although the location of these enzymes would indicate that AChE is more easily affected.

No significant changes were found between the total ATPase and the $\mathrm{Mg}^{2+}$-ATPase inhibitions. Only 1,1,2,2-tetrachloroethane inhibited the total ATPase significantly more than $\mathrm{Mg}^{2+}$-ATPase. Synaptosomal $\mathrm{Na}^{+}-\mathrm{K}^{+}$-ATPase, and $\mathrm{Mg}^{2+}$-ATPase also have identical sensitivities to local anesthetics (24). This phenomenon may indicate a structural relationship, similarity, or identity between these two proteins. The alcohols tested had no significant effects on the enzyme activities at the concentrations used. Higher concentrations of alcohols have been shown to inhibit synaptosomal enzymes (19-22).

The present results suggest that organic solvents interact with membrane-bound integral proteins even at concentrations too low to cause any changes in the lipid components of the membrane. Not even clinical concentrations of anesthetics have been found to cause any changes in the bilayer structure in short exposures (2). The studies of Greenberg \& Tsong $(25,26)$ indicate that the local anesthetic site in the membrane is an integral protein. Thus the changes in the integral enzymes AChE and ATPase may be the critical factor which determines the anesthetic CNS effect of solvents.

\section{References}

1. Dodson BA, Moss J. Molecular mechanisms of action of general anesthetics. Mol Cell Biochem 1984;64:97103.

2. Franks NP, Lieb WR. Where do general anaesthetics act? Nature 1978;274:339-42.

3. Franks NP, Lieb WR. Do general anaesthetics act by competitive binding to specific receptors? Nature 1984; 310:599-601.

4. Franks NP, Lieb WR. Mapping of general anaesthetic target sites provides a molecular basis for cut off effects. Nature 1985;315:349-51.

5. Korpela M, Tähti $H$. The effect of selected organic solvents on intact human red cell membrane acetylcholinesterase in vitro. Toxicol Appl Pharmacol 1986; $85: 257-62$.

6. Korpela M, Tähti H. Effects of industrial organic solvents on human erythrocyte membrane adenosine triphosphatase activities in vitro. Scand $\mathbf{J}$ Work Environ Health $1987 ; 13: 513-7$. 
7. Mäkinen E, Korpela M, Tähti H. Changes in trichloroethylene-treated rat erythrocyte membranes in vitro. Drug Chem Toxicol 1988;11:1-11.

8. Nagy A, Delgado-Escueta AV. Rapid preparation of synaptosomes from mammalian brain using nontoxic isoosmotic gradient material (Percoll). J Neurochem 1984; 43:1114-23.

9. Ellman GL, Courtney KD, Andres V Jr, Featherstone RM. A new and rapid determination of acetylcholinesterase activity. Biochem Pharmacol 1961;7:88-95.

10. Lowry OH, Lopez JA. The determination of inorganic phosphate on the presence of labile phosphate esters. J Biol Chem 1946;1621:421-8.

11. Lowry OH, Rosenbrough NJ, Farr AL, Randall RJ. Protein measurement with the Folin phenol reagent. J Biol Chem 1951;193:265-75.

12. Marchesi VT, Furthmayr H, Tomita M. The red cell membrane. Annu Rev Biochem 1976;45:667-98.

13. Bond GH, Hudgins AM. Inhibition of ATPase activity in human red cell membranes by tetracaine. Biochem Pharmacol 1976;25:267-70.

14. Garcia-Martin E, Cutirréz-Merino C. Local anesthetics inhibit the $\mathrm{Ca}^{2+}-\mathrm{Mg}^{2+}-\mathrm{ATP}$ ase activity of rat brain synaptosomes. J Neurochem 1986;47:668-71.

15. Haque SJ, Poddar MK. Lignocaine: inhibiting effect of synaptosomal and erythrocyte membrane-bound acetylcholinesterase activity. Biochem Pharmacol 1983;32: 3443-6.

16. Seeman P. Membrane actions of anesthetics and tranquilizers. Pharmacol Rev 1972;24:583-655.

17. Aloni B, Livne A. Acetylcholinesterase as a probe for erythrocyte membrane intactness. Biochim Biophys Acta 1974;339:359-66.

18. Sawas AH, Gilbert JC. Possible mechanism of inhibition by lipid peroxidation of ATPase activities of rat ce- rebral cortex synaptosomes. Arch Int Pharmacodyn Ther 1979;269:4-11.

19. Garrett KM, Ross DH. Effects of in vivo ethanol administration on $\mathrm{Ca}^{2+} / \mathrm{Mg}^{2+}$-ATPase and ATP-dependent $\mathrm{Ca}^{2+}$ uptake activity in synaptosomal membrane. Neurochem Res 1983;8:1013-28.

20. Lin DC. Involvement of the lipid and protein components of $\left(\mathrm{Na}^{+} \mathrm{K}^{+}\right)$-adenosinetriphosphatase in the inhibitory action of alcohol. Biochem Pharmacol 1980; 29:771-5.

21. Nhamburo PT, Salafsky BP, Hoffman PL, Tabakoff B. Effects of short-chain alcohols and norepinephrine on brain $\left(\mathrm{Na}^{+}, \mathrm{K}^{+}\right)$ATPase activity. Biochem Pharmacol 1986;35:1987-92.

22. Rangaraj $\mathbf{N}$, Kalant $\mathbf{H}$. Interaction of ethanol and $\left(\mathrm{Na}^{+} \mathrm{K}^{+}\right)$ATPase. Can J Physiol Pharmacol 1979;57: 1098-106.

23. Zolese G, Mazzanti L, Leporoni P, Lenaz G. Molecular mechanism of anesthesia: kinetic studies on erythrocyte ghost acetylcholinesterase. Boll Soc Ital Biol Sper 1979;55:511-516.

24. Sidek HM, Nyquist-Battie C, Vanderkooi G. Inhibition of synaptosome enzymes by local anesthetics. Biochim Biophys Acta 1984;801:26-31.

25. Greenberg M, Tsong TY. Binding of quinacrine, a fluorescent local anesthetic probe to mammalian axonal membranes. J Biol Chem 1982;257:8964-71.

26. Greenberg M, Tsong TY. Detergent solubilization and affinity purification of a local anesthetic binding protein from mammalian axonal membranes. J Biol Chem 1984;259:13241-5.

Received for publication: 5 July 1988 